\title{
Predation on postlarvae and juveniles of the shore crab Carcinus maenas: importance of shelter, size and cannibalism
}

\author{
P-O. Moksnes ${ }^{1, *}$, L. Pihl ${ }^{1}$, J. van Montfrans ${ }^{2}$ \\ ${ }^{1}$ Göteborg University, Kristineberg Marine Research Station, S-45034 Fiskebäckskil, Sweden \\ ${ }^{2}$ Virginia Institute of Marine Science, The College of William and Mary, Gloucester Point, Virginia 23062, USA
}

\begin{abstract}
Settlement and early juvenile stages are considered a bottleneck in the life history of many epibenthic organisms because of high predation mortality. Nursery habitats may play an important role in mitigating settlement and post-settlement mortality by providing refuge from predation. We examined these relationships in postlarvae and early juvenile stages of the shore crab Carcinus maenas $\mathrm{L}$. in laboratory and field tethering experiments. We studied habitat and size related habitat mortality using postlarvae and young juvenile crabs as prey, and various predators, including juvenile conspecifics, in several habitats common in shallow $(0$ to $1 \mathrm{~m}$ ) soft bottom nursery areas on the Swedish west coast. Settling mortality was high in open sand ( 80 to $90 \%)$, whereas a significant habitat refuge was obtained in mussel beds, eelgrass and filamentous green algae, the latter yielding the lowest mortality $(13$ to $14 \%)$. Small differences in structural complexity of ephemeral macroalgae dramatically affected predation mortality of trist instar crabs, with a significant refuge obtained only in diyde of medium complexity. Predation rate on tethered crabs in the field was high (52 to $67 \%$ ) only on the smallest crabs $(<5 \mathrm{~mm}$ carapace width, $C W$ ), which obtained a significant refuge in the eelgrass habitat compared to open sand. Mortality for larger crabs ( 5 to $25 \mathrm{~mm} \mathrm{CW}$ ) was low $(<10 \%)$ and similar in sand and eelgrass habitats. Our results indicate that predation is an important process that can create a bottleneck for juvenile shore crab populations during settlement and early juvenile stages, mediated by the availability of nursery habitats. Postlarvae obtained refuge from predation in several different habitats, suggesting that the recruitment of juvenile shore crabs will be less affected by temporal and spatial variation of any single habitat type. The strong size refuge for crabs larger than $4 \mathrm{~mm} C W$ indicates that key predators are small. We suggest that cannibalistic juveniles, which caused predation rates similar to or higher than all other investigated predators, are dominant predators on settling postlarvae and young juvenile crabs in nursery areas. We further propose that habitat- and size-specific predation by small epibenthic predators are an important selective force in habitat selection by postlarvae and ontogenetic shifts in habitat use by juveniles.
\end{abstract}

KEY WORDS: Bottleneck - Nursery habitats - Size refuge $\cdot$ Habitat complexity $\cdot$ Settlement $\cdot$ Megalopa Macroalgae -Skagerrak-Kattegat

\section{INTRODUCTION}

Settlement, the transition from a pelagic larval to a benthic phase (Scheltema 1974), and early juvenile stages are thought to be critical periods in the life cycle of many benthic organisms because of high predation pressure, causing a bottleneck in the recruitment

•E-mail: p.moksnes@kmf.gu.se
(Gaines \& Roughgarden 1987, Menge \& Sutherland 1987, Smith \& Herrnkind 1992, Eggleston \& Armstrong 1995, Gosselin \& Qian 1996, 1997). In support of this concept, young juveniles of motile benthic organisms are often found concentrated in structurally complex microhabitats that provide refuge from predation (e.g. shore crabs in mussel beds: Klein-Breteler 1976; blue crabs in seagrass beds: Heck \& Orth 1980; lobsters in cobblestones: Wahle \& Steneck 1991; spiny lobsters in macroalgae: Hermkind \& Butler 1986; fish in macro- 
algae: Carr 1994), suggesting that these nursery habitats play an important role in the survival and recruitment of the juvenile population. Habitat-specific predation rates have been demonstrated for juvenile stages of several benthic organisms (Wilson et al. 1987, Barshaw \& Able 1990b, Smith \& Herrnkind 1992, Fernandez et al. 1993a) and are often suggested as the proximate factor responsible for the non-random distribution of juveniles. However, this explanation has rarely been tested against competing hypotheses of passive or active habitat selection of postlarvae, or migration of juveniles of motile species after settlement to meet shelter or food requirements. Furthermore, most studies have been performed on older juveniles long after settlement (discussed by Keough \& Downes 1982, Connell 1985), and less is known about the predation rates and the effects of different habitats during settlement and metamorphosis. Postlarvae and early juveniles may face a different suite of predators than do larger juveniles (e.g. small benthic predators common in complex habitats, including older conspecifics). Settling postlarvae and different juvenile stages may therefore use different nursery habitats, and migrate between habitats to meet requirements of refuge and food, as they grow into different size-refuges from predation, resulting in one or several ontogenetic habitat shifts (Stein \& Magnuson 1976, Smith \& Herrnkind 1992, Eggleston 1995)

Many biotic nursery habitats show high spatiotemporal variation that could impact recruitment (Carr 1994). However, few studies have compared the refuge value of different potential nursery habitats and evaluated the ability of settling postlarvae and young juveniles to use habitats opportunistically (but see Barshaw et al. 1994, Dittel et al. 1996).

Finally, recent studies have demonstrated the importance of intra-specific predation on larvae and young juveniles for post-settlement mortality (Kurihara \& Okamoto 1987, Fernandez et al. 1993a, b, Perkins-Visser et al. 1996, Lovrich \& Sainte-Marie 1997, Moksnes et al. 1997). Accumulation of high densities of different size classes of juveniles in nursery habitats during the recruitment season could create favorable conditions for cannibalistic interactions. These interactions could regulate the recruitment if the cannibalism is densitydependent, imparting stability in the populations with minimal time-lag effect (Polis 1981).

\section{THE STUDY SYSTEM}

The shore crab Carcinus maenas L. is an epibenthic omnivore that is widely distributed on both hard and soft intertidal and shallow subtidal substrata. It is native to northwestern Europe, but also found in the northwestern Atlantic, and has recently been invading the North Pacific, South Australia and South Africa (Cohen et al. 1995 and references therein). It feeds opportunistically on various benthic species and is an important predator of the macrofauna in the benthic community (Ropes 1968, Klein-Breteler 1976, Scherer \& Reise 1981, Pihl \& Rosenberg 1982, Jensen \& Jensen 1985, Pihl 1985a, b, Sanchez-Salazar et al. 1987). The shore crab has a complex life cycle. On the Swedish west coast the megalopa (postlarva) settles between June and October (Moksnes unpubl. data), and peak numbers of 0-group juveniles are usually found in late July to September (Eriksson \& Edlund 1977, Pihl 1985b). Juvenile shore crabs (0- and 1-group; 1 to $25 \mathrm{~mm}$ spine-to-spine carapace width, CW) are found mainly in shallow $(<1 \mathrm{~m})$ soft sediment bays on the Swedish west coast, where they concentrate at high densities in structurally complex habitats (over 200 juvenile crabs $\mathrm{m}^{-2}$; Moksnes unpubl. data), primarily in blue mussel beds (Mytilus edulis L.; Eriksson \& Edlund 1977, Pihl \& Rosenberg 1982), but also in seagrass beds (Zostera marina L.i Pihl \& Rosenberg 1.982, Baden \& Pihl 1984) and in filamentous macroalgae (Isaksson \& Pihl 1992). There are no quantitative data available on larval supply and little is known about the initial distribution of megalopae and mortality rates during settlement. In Sweden, shore crabs attain sexual maturity during their second year (Eriksson \& Edlund 1977) when they disperse from nursery areas to adjacent deeper waters, including hard substrata. The dominant predators in unvegetated areas in shallow bays are brown shrimp Crangon crangon L., shore crabs, gobiids Pomatoschistus minutus Pallas and P. microps Krøyer, and juvenile flatfish Pleuronectes platessa L. and Platichthys flesus L.; most of these occasionally include juvenile shore crabs in their diet (Pihl \& Rosenberg 1984, Pihl 1985a). In vegetated areas and in mussel beds, shore crabs and grass shrimp Palaemon adspersus and $P$. elegans Rathke dominate, and 2 benthic fish, sculpin Myoxocephalus bubalis Euphrasen and Gobius niger L., which are potential predators on juvenile shore crabs, are common (Baden \& Pihl 1984, Pihl 1985b). Negative correlation between 1 - and 0 group shore crabs has led to suggestions that populations could be regulated within the species (Pihl \& Rosenberg 1982), but little is known about cannibalistic interactions within and between year classes. In recent years, as a result of eutrophication, the abundance of ephemeral benthic macroalgae has increased on the Swedish west coast, and today they dominate many shallow bays during the summer months (Pihl et al. 1995). These algae show high spatial and temporal variation in distribution and species composition (Pihl et al. 1996), and a wide range of structural complexity (i.e. surface area per unit volume), from large foliose 
species to finely branched filamentous algae. The impact of the mosaic-like distribution and high spatiotemporal variation of potential nursery habitats on shore crab recruitment is largely unknown.

In the present study we used laboratory and field experiments to investigate the impact of predation on survival of settling postlarval and juvenile shore crabs, and the refuge effect of several different habitats, using several different predators including cannibalistic older instars. In particular we addressed the following: (1) Can predation cause a bottleneck for juvenile shore crab populations during settlement or early juvenile stages? (2) Do predation rates in different habitats reflect the distribution of juvenile crabs? (3) Is survival during settlement and early juvenile stages dependent on the refuge from one particular habitat? (4) Do juvenile crabs at some stage obtain a size refuge from predation? (5) Are cannibalistic older juveniles a dominant predator?

\section{MATERIAL AND METHODS}

Three laboratory experiments and 1 field experiment were conducted during summer and fall, 1993 to 1995 , at Kristineberg Marine Research Station and in the area surrounding the Gullmarsfjord on the Swedish west coast $\left(56^{\circ} 15^{\prime} \mathrm{N}, 11^{\circ} 35^{\prime} \mathrm{E}\right)$. This area is affected by the Baltic current, with surface salinities normally between 20 and 30 PSU; summer and fall temperatures in the shallow bays vary between 10 and $21^{\circ} \mathrm{C}$, and the tidal amplitude is around $0.2 \mathrm{~m}$.

The 4 experiments addressed: (1) the effect of habitat (blue mussel, eelgrass, filamentous green algae and sand) on survival of shore crab megalopae during settlement and metamorphosis, using juvenile shore crab and brown shrimp as predators; (2) the effect of the structural complexity of benthic ephemeral macroalgae on survival of the first instar crabs using brown shrimp as predators; (3) the effect of prey size and predator species and size on survival of megalopae and juvenile shore crabs; and (4) the effect of habitat (eelgrass and sand) and prey size on relative predation rates on juvenile shore crabs, using field tethering techniques.

General laboratory experimental procedures. All experimental tanks used in the laboratory experiments were provided with approximately $4 \mathrm{~cm}$ depth of sieved $(<750 \mu \mathrm{m})$ dry beach sand and filtered $(<750 \mu \mathrm{m})$ surface water from a nearby bay. Two sources of light were used in the laboratory giving $16 \mathrm{~h}$ light: $6 \mathrm{~h}$ dark and $1 \mathrm{~h}$ of diffuse light at dusk and dawn in all experiments, approximating natural fall light conditions in Sweden. Megalopae used in the experiments were collected daily from the surface plankton using artificial settlement substrata (see van Montfrans et al. 1990 for details), kept in $50 \mathrm{l}$ aerated tanks and fed fresh blue mussel mantle prior to use. Prey crabs were raised from megalopae in $10 \mathrm{l}$ aerated tanks and fed blue mussels until molting into the appropriate juvenile instar. Predators were collected in shallow bays in the Gullmarsfjord with hand nets and kept in the laboratory in aerated circular tanks with sediment and shells while being fed blue mussel for a minimum of $7 \mathrm{~d}$ before being used. Only predators observed to feed on mussel tissue were used, and each predator was used only once. All animals were measured alive with transparent rulers and survivors were released at the end of each experiment. Except where otherwise stated, predators were allowed to adapt in the experimental tanks for $24 \mathrm{~h}$ without food before prey were added, which denoted the beginning of a trial. All habitats were collected in shallow bays next to the marine station, rinsed in fresh water and cleaned of epiphytes and fauna prior to use. Upon termination of each trial, habitats were carefully rinsed and soaked in fresh water for a minimum of $1 \mathrm{~h}$; tank contents, including sediment, and habitat rinse water were sieved through $750 \mu \mathrm{m}$ mesh and all remaining animals were enumerated and measured. Dead, uneaten prey were counted but excluded from statistical analyses. Treatments were randomly allocated between tanks and replicates were run in time series in all experiments.

All data were tested for homoscedasticity with Cochran's C-test (Sokal \& Rohlf 1981) and transformed only if found heteroscedastic before the ANOVA were performed. A posteriori multiple comparisons were carried out with the Student-Newman Keuls (SNK) procedure. When an interaction factor was significant, relationships among the levels of experimental factors were examined across each level in turn, using the SNK procedure. If an interaction factor was not significant in a mixed-model ANOVA, post hoc pooling was performed to test the fixed factor (Underwood 1997).

Expt 1: effect of predation and habitats on settlement mortality. In a laboratory predation experiment conducted between 12 August and 17 September 1995 we studied the effect of predation on mortality of shore crab megalopae during settlement and metamorphosis in different habitats. We used 20 live shore crab megalopae as prey in $48 \mathrm{~h}$ trials, using 4 different habitats (blue mussel, eelgrass, filamentous green algae and sand) and 3 different predator treatments: (1) 3 fifth to sixth instar ( 6 to $7 \mathrm{~mm} \mathrm{CW}$ ) juvenile shore crab predators, (2) 3 brown shrimp predators (6 to $7 \mathrm{~mm}$ carapace length, CL) and (3) control, no predator treatment. To separate cannibalism between megalopae from losses due to handling in the control treatment, we ran a second series of control trials for each habitat which were ended $<5$ min after the megalopae were added (before any cannibalism could occur). 
The megalopal density (equivalent to approximately 105 megalopae $\mathrm{m}^{-2}$ ) was selected to reflect a natural moderate settlement density (Moksnes unpubl. data). Fifth instar shore crabs were chosen as predators because they co-occur in high abundance with megalopae within the nursery habitats during the settlement season as both 1-group (late settlers from the previous year) and 0-group individuals (early settlers from the same year; Pihl \& Rosenberg 1982), and therefore could potentially be important predators on settling megalopae. Brown shrimp was chosen as a predator because it is the most abundant predator on the open sand surrounding the complex habitats (Pihl $\&$ Rosenberg 1982). The predator density chosen (equivalent to approximately 16 predators $\mathrm{m}^{-2}$ ) represented, for juvenile shore crabs, natural low to medium densities in the complex habitats and an unusually high density on sand (Eriksson \& Edlund 1977, Pihl \& Rosenberg 1982, Isaksson \& Pihl 1992). For adult brown shrimp, this density reflected a natural medium density on sand and an unusually high density in the complex habitats (Pihl \& Rosenberg 1982, Moksnes unpubl. data).

Habitat complexity was varied in each mesocosm by using 1 of 4 treatments: sand with 75 live adult 70 to $80 \mathrm{~mm}$ ) blue mussels, sand with approximately 150 shoots $(10$ to $30 \mathrm{~cm})$ of live eelgrass, sand with approximately $500 \mathrm{ml}$ of filamentous green algae (mean dry weight 5.1 to $5.3 \mathrm{~g}$ ), or bare sand. Blue mussels were left in flow-through tanks 3 to $5 \mathrm{~d}$ prior to use to develop small and tightly packed beds with a new web of byssus threads. Eelgrass was planted uniformly in small bundles ( 2 to 6 shoots) in the mesocosms at densities (approximately 750 shoots $\mathrm{m}^{-2}$ ) equivalent to natural medium densities in shallow bays in this area (Baden \& Pihl 1984). The filamentous green algae (Chlorophyta) consisted of a mixture of branched Enteromorpha spp. and Cladophora spp. with stem diameters between 40 and $1000 \mu \mathrm{m}$.
We used 10 cylindrical flow-through $\left(90 \mathrm{l} \mathrm{h}^{-1}\right)$ mesocosms $\left(0.19 \mathrm{~m}^{2}\right)$ with approximately $40 \mathrm{~cm}$ water depth above the sand substratum (total volume $=80 \mathrm{l}$ ). Water entered along the tank wall and left at the surface in the center through a tube equipped with a $750 \mu \mathrm{m}$ mesh, creating a continuous circular current. Aeration was provided below the mesh to discourage megalopal settlement there. Megalopae and first instar crabs found on the mesh at the end of a trial were excluded from statistical analyses. The $750 \mu \mathrm{m}$ filter on the inflowing water prevented 'wild' megalopae from entering the mesocosm, but allowed small alternative prey (dominated by juvenile Littorina spp., Hydrobia spp., copepods, juvenile bivalves and parts of barnacles) to enter. Water temperature and salinity in the mesocosms varied between 15 and $21^{\circ} \mathrm{C}$ and between 23 and 30 PSU during the experiment.

Mortality of megalopae (number missing) served as the dependent variables in a balanced $(n=4)$, orthogonal, fixed 2-factor ANOVA model with Predation and Habitat as the independent variables. Megalopal metamorphosis rate (number metamorphosed) was analysed as the dependent variable and Habitat as the independent variable in a complementary test using only the data from the control treatments.

Expt 2: effect of algal structural complexity on post-settlement mortality. The importance of algal structural complexity (i.e. surface area per unit volume) as a predation refuge for juvenile shore crabs was tested in a laboratory experiment in September 1995. We used 20 live first instar juvenile shore crabs as prey and 1 brown shrimp ( 7 to $9 \mathrm{~mm} \mathrm{CL}$ ) as the predator in the $24 \mathrm{~h}$ trials. Small static circular tanks (bottom area $0.031 \mathrm{~m}^{2}, 10$ l) were used to increase the encounter rate and the importance of the refuge habitat. Five species of algae, common in shallow soft sediment bays, were tested in separate treatments with 1 additional treatment containing sand only (Table 1). Control trials, without the presence of

Table 1. Experimental design for analysis of the effect of algal structural complexity (i.e. surface area per unit volume) on survival of 20 first instar juvenile prey crabs (Carcinus maenas) using 1 brown shrimp as predator and 6 different habitat treatments $(\mathrm{n}=4$ ). Control trials $(n=3)$ were run in the same habitats but without the predator. Approximately 100 ml algae was used in each treatment. Data are given for the range (mean) of stem diameter or leaf width for each algal species, and the mean stem radius or leaf thickness used for the estimation of total surface area for each algae (see text for details). DW: dry weight of algae

\begin{tabular}{|c|c|c|c|c|}
\hline Habitat & $\begin{array}{l}\text { Leaf/stem } \\
\text { width }\end{array}$ & $\begin{array}{c}\text { Leaf/stem } \\
\text { thickness/radius ( } \mu \mathrm{m})\end{array}$ & Surface area $\left(\mathrm{m}^{2}\right)$ & Mean DW $(g)$ \\
\hline Sand & - & - & - & - \\
\hline Ulva lactuca & $5-15(10) \mathrm{cm}^{\mathrm{d}}$ & $100^{a}$ & 2.0 & 1.54 \\
\hline Enteromorpha compressa & $0.5-5$ (1) $\mathrm{mm}^{\mathrm{a}}$ & $100^{\mathrm{a}}$ & 2.2 & 0.94 \\
\hline Cladophora sp. & $40-130(85) \mu \mathrm{m}$ & 42.5 & 4.7 & 1.20 \\
\hline Enteromorpha clathrata & $20-90(55) \mu \mathrm{m}$ & 27.5 & 7.3 & 1.43 \\
\hline Ectocarpus siliculosus & $10-40(25) \mu \mathrm{m}$ & 12.5 & 16 & 0.87 \\
\hline
\end{tabular}


predators, were run in all habitats. Approximately $100 \mathrm{ml}$ of each algal habitat (measured by compressing the soft algae into a cup) was used in each tank. To obtain a measurement of the structural complexity of each alga, a rough estimate of its surface area was performed. The relation between the volume and the surface area of a cylinder (excluding the area on the top and bottom), $A=(2 / r) V$, where $A=$ surface area of algae, $r$ = radius of the average filament, and $V=$ volume of algae, was used to calculate the surface area of the filamentous algae. The length and frequency of branching of the filaments could be disregarded in these algae since the area at the top of all filaments constitutes less than $2.5 \%$ of the total surface area if the length:diameter ratio of the filament is above 10 . For the 2 more foliose species (Ulva lactuca and Enteromorpha compressa), the surface area of the large leaf surface was calculated using the following relation between volume and surface area: $A=(2 / d) V$, where $d=$ the thickness of the leaf. The surface area of the leaf edges was subsequently added, based on average leaf width (Table 1). These calculations result in overestimations of the surface area since the algae were not perfectly packed into the measuring cups, but the error should be similar among all the algae. Water temperature and salinity in the experimental tanks varied between 12.9 and $19.4^{\circ} \mathrm{C}$ and between 23 and 30 PSU during the experiment. Oxygen levels near the bottom in tanks during the night varied between 20 and $45 \%$ saturation in the different treatments.

Mortality of first instar crabs served as the dependent variable in a balanced, orthogonal, fixed 1-factor ANOVA model with Habitat as the independent variable.

Expt 3a: observational study of predator consumption rates and prey size refuges. To identify potential species and size classes of predators on megalopae and juvenile shore crabs, with emphasis on juvenile cannibalism, we performed a laboratory study testing several size classes of 7 of the most abundant epibenthic predator species in shallow bays on the Swedish west coast: cannibalistic juvenile shore crabs, brown shrimps, grass shrimps Palaemon adspersus and $P$. elegans, gobiids Pomatoschistus minutus and Gobius niger, and juvenile plaice. We used 3 size classes of juvenile shore crabs as prey (modified from Mohamedeen \& Hartnoll 1989): 10 to 20 megalopae or first instar crabs $(1.5 \mathrm{~mm} \mathrm{CW}), 6$ third to fourth instar crabs ( 3 to $4 \mathrm{~mm} \mathrm{CW}$ ), and 3 fifth to sixth instar crabs (6 to $7 \mathrm{~mm} \mathrm{CW}$ ) to identify a potential size refuge from predation. The experiment was carried out during the summer and fall of 1994 and 1995. We used small static circular tanks (bottom area $0.031 \mathrm{~m}^{2}, 10 \mathrm{l}$ ) with only one shell half as the habitat, to optimize the conditions for predation, leaving only prey size as a refuge. When low predation rates were found using large predators, a $0.125 \mathrm{~m}^{2}, 40 \mathrm{l}$ tank was also used in replicated trials with the same density of prey to decrease a possible negative effect of tank size on predation rates. Each trial was run for $24 \mathrm{~h}$. Water temperature and salinity in the experimental tanks varied between 11 and $19^{\circ} \mathrm{C}$ and between 20 and 32 PSU during the experiment. No statistical test was applied to this experiment. Instead we noted which predator species and size classes could successfully feed on each prey size class, and calculated the mean and maximum consumption rate.

Expt 3b: cannibalistic rates with alternative food. To test if cannibalism between juvenile crabs could be an artifact caused by starvation of predators and lack of alternative food, we performed a complementary experiment in the $10 \mathrm{l}$ tanks described above. We used 1 fourth to sixth instar juvenile crab (4.7 to $8.7 \mathrm{~mm} \mathrm{CW}$; mean $5.9 \mathrm{~mm}$ ) as the predator and 20 first instars as prey in 4 different treatments $(n=4)$ : (1) $24 \mathrm{~h}$ starved predators and no alternative food during the experimental trial, (2) predators fed blue mussel tissue until the start of experiment, but no alternative food during the trial, (3) predators fed blue mussels both before and during the trial and (4) control, no predator and no alternative food during the trial. Blue mussel tissue used in the trials was weighed (wet weight) before and after the experiment. Each experimental trial was run for $12 \mathrm{~h}$ (6 $\mathrm{h}$ darkness), from evening to morning. Water temperature and salinity in the experimental tanks varied between 15.0 and $17.8^{\circ} \mathrm{C}$ and between 22 and 23 PSU during the experiment.

Mortality of first instar crabs served as the dependent variable in a balanced, orthogonal, fixed, 1-factor ANOVA model with Treatment ( 1 to 4 ) as the independent variable.

Expt 4: field experiment-habitat and size refuges. We experimentally examined the effect of habitat (eelgrass and sand), prey size (1 to $25 \mathrm{~mm} \mathrm{CW}$ ) and location ( 2 bays) on relative rates of predation on juvenile shore crabs in the field, using tethering techniques similar to those used by Heck \& Thoman (1981) and Wilson et al. (1987). A short (5 cm) light-weight monofilament line was glued to the carapace of the crab using 'super glue' (cyanoacrylate) and attached to a metal rod which was pushed completely into the sediment. The crabs were randomly distributed within the 2 habitats in subtidal areas $(0.5$ to $1.5 \mathrm{~m}$ depth) of 2 shallow bays, Bokevik and Torseröd, in the Gullmarsfjord (Fig. 1) and recovered approximately $24 \mathrm{~h}$ later. Loss of a crab was only scored as predation when a broken piece of carapace remained on the line, or when the line was cut. Molted crabs were easy to dis- 


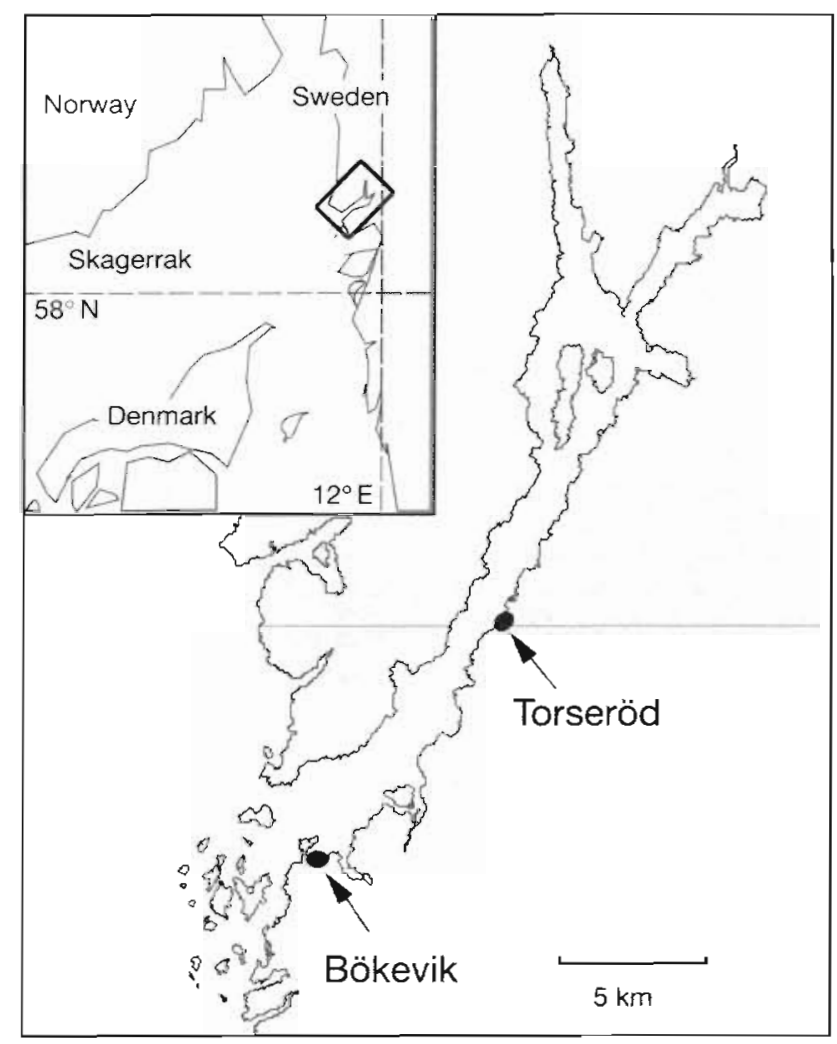

Fig. 1 Location of the Gullmarsfjord (western Sweden) and the 2 bays, Bökevik and Torseröd, where the tethering experiments and field samples were carried out

cern from predation since their entire carapace remained on the tether, and were excluded from analysis of relative predation rates, as were intact dead crabs. The distinction between losses due to predation and molt was studied in a laboratory pilot study using adult shore crabs, juvenile cod Gadus morhua L. and sculpin as predators, and juvenile crabs 5 to $25 \mathrm{~mm} \mathrm{CW}$ as prey

The tethering experiment was carried out in 2 different seasons in 1993: once in June, before the settlement season, using 3 size classes of the 1 -group juvenile crabs $(5.0-9.0,10-18$ and $21-25 \mathrm{~mm})$, and once in September using newly settled juveniles of the 0 -group crabs $(1-2.5,2.6-4.0$ and 5.0-9.0 mm). Hence, only the 5-9 $\mathrm{mm}$ size class was assessed in both seasons. On each tethering date, 10 crabs of each size class (only 5 crabs of the 2 smallest size classes in September) were individually tethered in each habitat and in the 2 different bays. The experiment was replicated 6 times in both seasons (18-24 June, and $1-3$ and $7-9$ September), using a total of approximately 1200 crabs. Control crabs were tethered in cages without preda. tors for each treatment combination in June to assess natural mortality and escape rates from the tether.
Proportional relative predation rate [no. of crabs scored as eaten / (no. of crabs tethered - no. of crabs molted]] and proportional molt rate (no. crabs molted/ no. of crabs tethered) served as the dependent variables in 4 separate orthogonal, mixed-model 3 -factor ANOVA models with Size. Habitat (fixed factors) and Location (random factor) as the independent variables in June and September. To compare relative predation rates between the 2 seasons for the $5-9 \mathrm{~mm}$ CW size class, a complementary orthogonal, mixed-model 3factor ANOVA was carried out using proportional relative predation rate as the dependent variable and Month (June, September), Habitat and Location as independent variables.

Field densities and size distribution of juvenile shore crabs in the 2 habitats were estimated in both bays using a portable drop trap $\left(0.5 \mathrm{~m}^{2}\right.$; Pihl \& Rosenberg 1982) after termination of the field experiment in September.

Tethering techniques have been used to assess relative predation rates in the field in different habitats for several species of decapod crustaceans (Heck \& Thoman 1981, Herrnkind \& Butler 1986, Wilson et al. 1987. Barshaw \& Able 1990b). The technique has been examined for interaction effects between treatment effects and tethering-artifacts effects (Peterson \& Black 1994) for different size classes of juvenile blue crabs Callinectes sapidus Rathbun tethered in eelgrass and sand (Pile et al. 1996). In the present study we used short tethers $(5 \mathrm{~cm}$ ) to minimize the risk of tangling. Observations in aquaria confirmed that tethered crabs were able to feed and bury, and that behavior of tether and untethered crabs was similar across habitats and prey sizes. In an attempt to identify if the predators differed in the 2 habitats we used underwater video cameras in the field and tethered crabs provided with small hooks during the June experiment, but did not identify any predators due to lack of attacks.

\section{RESULTS}

\section{Expt 1: effect of predation and habitats on settlement mortality}

Estimates of loss due to handling were low $2.6 \%$ in blue mussels, $1.7 \%$ in sand and $0 \%$ in the other 2 habitats) and remaining losses were therefore considered to be due to predation. Mean proportional metamorphosis rate of the settling megalopae in the control treatments varied between 50 and $95 \%$ (total mean $76 \%)$ and did not differ significantly between habitats (ANOVA; $F=2.29, \mathrm{df}=3,12, \mathrm{p}=0.13$ ). Because of the high variation in metamorphosis rate we performed 
an additional analysis to test if metamorphosis rates affected predation rates. The data were separated into 2 groups based on metamorphosis rates above or below 50\%. A 1-factor ANOVA, with megalopal mortality as the dependent variable and Molt rate (High, Low) as the independent variable, showed that mortality was similar among groups (26 and $27 \%$ mortality in the 2 groups having 90 and $41 \%$ metamorphosis rate, respectively; $F=0.003, \mathrm{df}=1,46, \mathrm{p}=0.95$ ).

Megalopal mortality differed significantly between habitats in the predator treatments $(13$ to $90 \%)$ but not in the control treatments $(2.5$ to $8.8 \%)$, causing a significant interaction effect between Habitat and Predation (ANOVA; $F=22.9, \mathrm{df}=6,36, \mathrm{p}=0.0001$; Fig. 2). On sand, cannibalistic juvenile shore crabs and brown shrimp caused 90 and $80 \%$ mortality, respectively, which were significantly higher than in the structurally complex habitats (SNK test, $\mathrm{p}<0.05$ ). Filamentous algae appeared to provide the best protection from predation by shrimp and crab predators, allowing only 13 and $14 \%$ mortality, compared to 21 and $32 \%$ in blue mussels and 19 and $33 \%$ in eelgrass, respectively. However, only filamentous algae and blue mussel treatments with crab predators differed significantly among the complex habitats. Predation caused a significant increase in mortality as compared to control treatments in all 4 habitats, except for shore crab in filamentous algae and brown shrimp in eelgrass. A trend of higher mortalities with crab predators compared to brown shrimp predators occurred in all habitats, but was only significant in the blue mussel treatment (SNK test, $\mathrm{p}<0.05$ ).

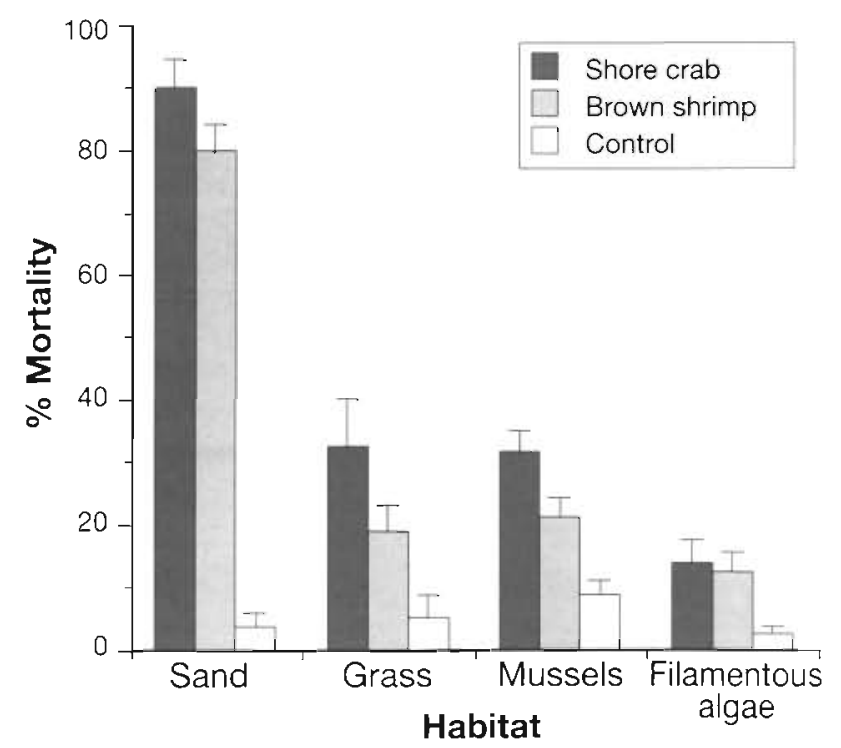

Fig. 2. Carcinus maenas. Mean percent mortality of settling shore crab megalopae (+SE) in 4 different habitats, using either 3 juvenile shore crabs (6 to $7 \mathrm{~mm} \mathrm{CW}$ ) or 3 brown shrimp ( 6 to $7 \mathrm{~mm} \mathrm{CL}$ ) as predators in $48 \mathrm{~h}$ trials

\section{Expt 2: effect of algal structural complexity on post-settlement mortality}

Mortality of first instar juvenile shore crabs by predation of brown shrimp was significantly reduced by algae of medium complexity (surface area 2.2 to $7.3 \mathrm{~m}^{2}$ per $100 \mathrm{ml}$ algae) compared to open sand, but not by algae of lower or higher complexity (surface area 0.40 and $16 \mathrm{~m}^{2}$ per $100 \mathrm{ml}$ algae, respectively; ANOVA; $F=23.5, \mathrm{df}=5,18, \mathrm{p}=0.0001$; SNK test, $\mathrm{p}<0.05$; Fig. 3). The 3 algae of medium complexity, Enteromorpha compressa (L.) Nees, Cladophora sp. and E. clathrata (Roth) Grev., yielded 8, 6 and $24 \%$ mortality, respectively, and did not differ significantly from each other. Mortality was significantly higher in sand ( $89 \%$ mortality), the foliose Ulva lactuca L. (70\% mortality) and the finely filamentous Ecto-

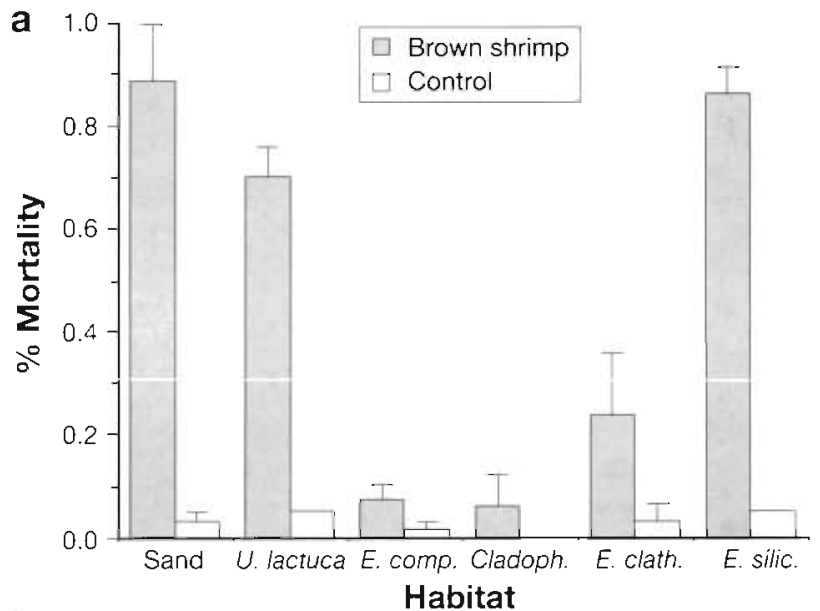

b

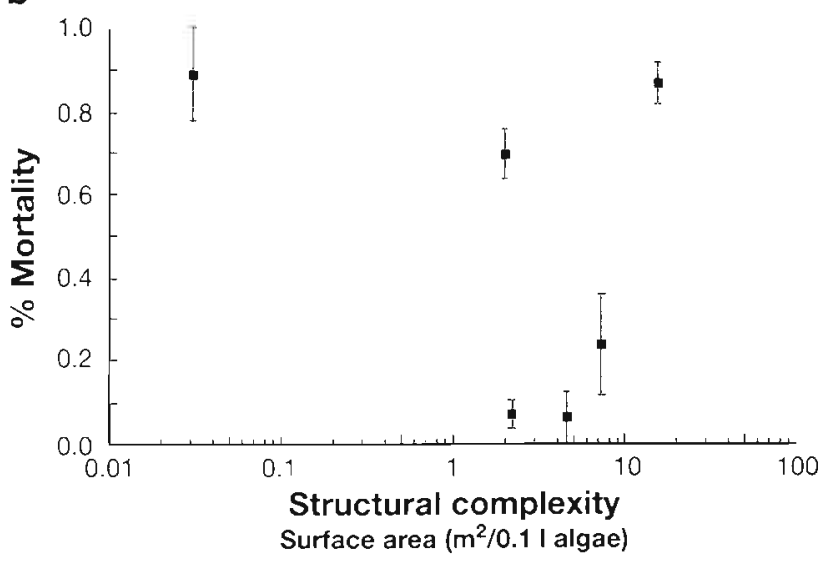

Fig. 3. Carcinus maenas. (a) Mean percent mortality of 20 first instar juvenile shore crabs $(+\mathrm{SE})$ in sand and 5 different algal habitats with increasing structural complexity - Ulva lactuca, Enteromorpha compressa, Cladophora sp., Enteromorpha clathrata, Ectocarpus siliculosus-- using 1 brown shrimp ( 7 to $9 \mathrm{~mm} \mathrm{CL}$ ) as the predators in $24 \mathrm{~h}$ trials. (b) Mean percent mortality in the predator treatment in relation to the total surface area of the sand and algae in each treatment 
carpus siliculosus (Dillwyn) Lyngb. (86\% mortality), which were not significantly different from each other (SNK tests at $p<0.05$ ). Losses in the control treatments varied between 0 and $5 \%$, and no crabs were found dead.

\section{Expt 3a: observational study of predator consumption rates and prey size refuges}

All investigated epibenthic predators (shore crab, brown shrimp, grass shrimps, gobiids and plaice), except the smallest juvenile stages, were efficient predators on megalopae and first juvenile shore crabs on the sand habitat, consuming 10 to 20 prey predator $^{-1} 24 \mathrm{~h}^{-1}$ (Table 2). Juvenile shore crab predators as small as $3 \mathrm{~mm}$ could effectively eat megalopae and first instar crab prey (up to 9 prey predator $^{-1} 24 \mathrm{~h}^{-1}$ ). The most efficient cannibalistic predators were between 5 and $20 \mathrm{~mm} \mathrm{CW}$, which repeatedly consumed all 20 prey in $24 \mathrm{~h}$. Shore crabs larger than $30 \mathrm{~mm}$ did not eat any megalopae or first instar crabs. Small juvenile brown shrimp (2 to $3 \mathrm{~mm}$ CL) consumed 3 to 4 prey predator ${ }^{-1} 24 \mathrm{~h}^{-1}$, and larger shrimp ( 4 to $9 \mathrm{~mm} \mathrm{CL}$ ) repeatedly ate all. available prey. Mortality in the control treatment, i.e. cannibalism between and among megalopae and first instar crabs, was $3 \%$ on average and never above $10 \%$

Larger juveniles or adults of all investigated predator species could efficiently consume the 3 to $4 \mathrm{~mm}$ CW juvenile crabs (Table 2). Most predator crabs $8 \mathrm{~mm} \mathrm{CW}$ or larger were efficient cannibals on this prey size class. Mortality in the control treatment was zero.

Only cannibalistic young adult shore crabs (30 to $35 \mathrm{~mm} \mathrm{CW}$ ) were able to eat the 6 to $7 \mathrm{~mm} \mathrm{CW}$ juvenile crabs (Table 2). Neither smaller nor larger conspecifics, nor any of the other predator species, were efficient predators on this prey class. Mortality in the control treatment was $2 \%$

Cannibalistic crabs showed consumption rates on all 3 prey size classes similar to or higher than those of the other investigated predator species.

Tabie 2. Results from Expt 3a. Consumption rates per 24 h of 7 epibentic predators on 3 prey size treatments of juvenile shore crab (Carcinus maenas): (1) 10 to 20 megalopae and first instar crabs, (2) six 3 to $4 \mathrm{~mm} \mathrm{CW}$ juvenile crabs and (3) three 6 to $7 \mathrm{~mm} \mathrm{CW}$ juvenile crabs. Size denotes predator size: carapace width for crabs, carapace length for shrimp, and total length for fish. Mean denotes mean consumption rate per predator and $24 \mathrm{~h}$, calculated from n replicates. Max. denotes the maximum consumption rate observed for 1 predator. "indicates that all available prey were consumed

\begin{tabular}{|c|c|c|c|c|c|c|c|c|c|c|c|c|c|}
\hline \multirow[t]{2}{*}{ Predator } & \multirow{2}{*}{$\begin{array}{c}\text { Size } \\
(\mathrm{mm})\end{array}$} & \multicolumn{4}{|c|}{ Megalopae and first instars } & \multicolumn{4}{|c|}{ Juveniles (3-4 mm) } & \multicolumn{4}{|c|}{ Juveniles $(6-7 \mathrm{~mm})$} \\
\hline & & n & Mean & $\mathrm{SD}$ & Max. & $\mathrm{n}$ & Mean & $\mathrm{SD}$ & Max. & $\mathrm{n}$ & Mean & SD & Max. \\
\hline \multirow[t]{11}{*}{ Carcinus maenas } & $>35$ & - & - & - & - & 4 & 1.2 & 2.5 & 5 & 5 & 0 & 0 & 0 \\
\hline & $30-35$ & 4 & 0 & 0 & 0 & 5 & 0.2 & 0.4 & 1 & 5 & 2.2 & 0.8 & 3 \\
\hline & $20-30$ & 5 & 12 & 8.4 & 18 & 2 & 4.5 & 2 & $6^{\circ}$ & 5 & 0 & 0 & 0 \\
\hline & $15-20$ & 2 & 18 & 3.5 & $20^{\circ}$ & 2 & 2 & 1.4 & 3 & - & - & - & - \\
\hline & $10-15$ & 5 & 1.5 & 6.3 & $20^{\circ}$ & 2 & 0.5 & 0.7 & 1 & - & - & - & - \\
\hline & $8-10$ & 5 & 19 & 2.2 & $20^{\circ}$ & 4 & 1.8 & 1.7 & 4 & - & - & - & - \\
\hline & $6-7$ & 5 & 17 & 3 & $20^{*}$ & 2 & 0.5 & 0.7 & 1 & - & - & - & - \\
\hline & 5 & 3 & 13 & 6.4 & $20^{\circ}$ & - & - & - & - & - & - & - & - \\
\hline & 4 & 6 & 9.7 & 5.6 & 17 & - & - & - & - & - & - & - & - \\
\hline & 3 & 4 & 4.5 & 3.9 & 9 & $=$ & - & - & - & - & - & - & - \\
\hline & 2 & 6 & 0.7 & 1 & 2 & - & - & - & - & - & - & - & - \\
\hline \multirow[t]{7}{*}{ Crangon crangon } & $11-12$ & - & - & - & - & 2 & 3.5 & 0.7 & 4 & 3 & 0 & 0 & 0 \\
\hline & $7-9$ & 3 & 13 & 0.6 & $20^{\circ}$ & - & - & - & - & - & - & - & - \\
\hline & $6-7$ & 6 & 18 & 3.2 & $13^{\circ}$ & - & - & - & - & - & - & - & - \\
\hline & $4-5$ & 3 & 13 & 0.6 & $13^{\circ}$ & - & - & - & - & - & - & - & -- \\
\hline & $3-4$ & 2 & 12 & 0 & 12 & & & & & & & & \\
\hline & $2-3$ & 2 & 3.5 & 0.7 & 4 & - & - & - & - & - & - & - & - \\
\hline & $<2$ & 4 & 0 & 0 & 0 & - & - & - & - & - & - & - & - \\
\hline \multirow[t]{3}{*}{ Palaemon adspersus } & $23-28$ & - & - & - & - & 5 & 1.6 & 0.6 & 4 & 4 & 0.3 & 0.5 & 1 \\
\hline & 1.6 & 2 & 15 & 0 & $15^{\circ}$ & - & - & - & - & - & - & - & - \\
\hline & $4-5$ & 2 & 8.5 & 0.7 & 9 & - & - & - & - & - & - & - & - \\
\hline Palaemon elegans & $14-16$ & 2 & 15 & 0.7 & $15^{\circ}$ & - & - & - & - & - & - & - & - \\
\hline \multirow[t]{2}{*}{ Pomatoschistus minutus } & $30-56$ & 3 & 12 & 0.6 & 13 & - & - & - & - & - & - & - & - \\
\hline & 12 & 1 & 5 & - & 5 & - & - & - & - & - & - & - & - \\
\hline Gobius niger & $70-130$ & 1 & 13 & - & 13 & 4 & 4.2 & 2.4 & $6^{*}$ & 3 & 0 & 0 & 0 \\
\hline Pleuronectes platessa & $33-60$ & 3 & 16 & 2.1 & 18 & 4 & 2.8 & 1.3 & 4 & 3 & 0 & 0 & 0 \\
\hline Control & - & 14 & 06 & 0.6 & 2 & 7 & 0 & 0 & 0 & 7 & 0.1 & 0.4 & 1 \\
\hline
\end{tabular}




\section{Expt 3b: cannibalistic rates with alternative food}

Juvenile shore crabs ( 4.7 to $8.7 \mathrm{~mm}$ CW) caused significant mortality of first instar prey (ANOVA; $F=5.96$, $\mathrm{df}=3,16, p=0.01$ ), irrespective of the presence of alternative prey. Predation rates did not differ significantly between treatments where predators were fed blue mussel mantle tissue before and during the experiment (mean $=4.0$ prey $12 \mathrm{~h}^{-1}$ ), where the predators were fed before but not during the trial (mean = 5.0 prey $12 h^{-1}$ ), or where the predators were starved both before and during the trial (mean $=6.2$ prey $12 \mathrm{~h}^{-1}$ ). Mortality in control treatments was $2 \%$ and significantly less than in all other treatments (SNK tests at $p<0.05$ ). The weight of the alternative food (blue mussel mantle tissue) did not decrease during the trials.

\section{Expt 4: field experiment-habitat and size refuges}

In June, relative predation rates on 1-group prey crabs (5 to $25 \mathrm{~mm} \mathrm{CW}$ ) were low ( 3 to $9 \%$ ) and did not differ significantly between habitats, prey size or the 2 investigated bays (Table 3, Fig. 4). Proportional molt rates of tethered crabs varied between 0 and $10 \%$, and did not differ significantly between any treatment (Table 3). None of the caged animals died or escaped the tether.

In September, relative predation rates on the 0-group crabs (1 to $9 \mathrm{~mm} \mathrm{CW}$ ) were significantly lower in the eelgrass habitat compared to the sand habitat for all 3 size classes, and decreased significantly from the smallest to largest size class in both habitats (Table 3, Fig. 4; SNK test, $\mathrm{p}<0.05$ ). The same result was found in both investigated bays. The smallest size class $(1.0$ to $2.5 \mathrm{~mm} \mathrm{CW}$ ) showed $67 \%$ mortality in sand and $52 \%$ in eelgrass, which was significantly higher than

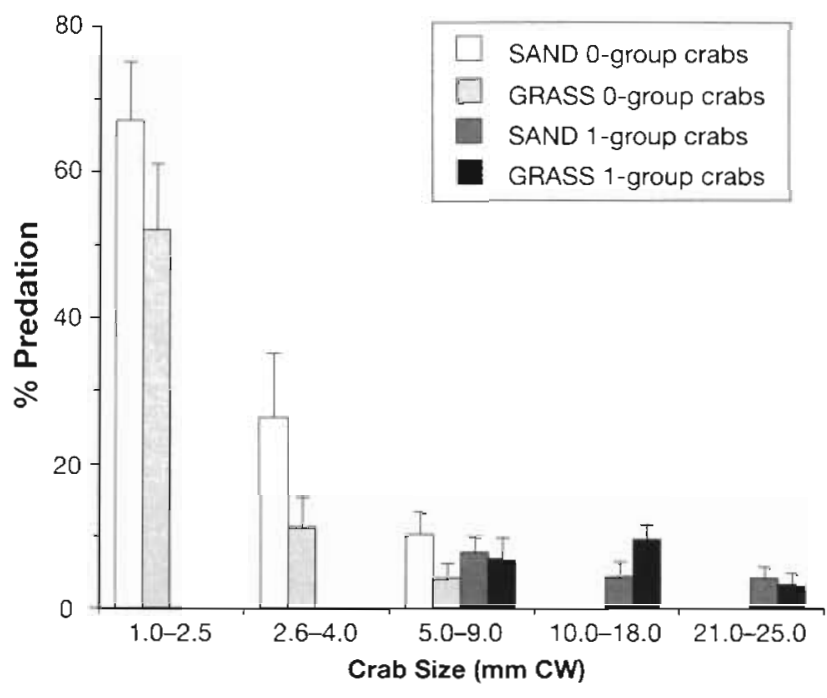

Fig. 4. Carcinus maenas. Mean percent predation (+SE) on 5 size classes of juvenile shore crabs tethered in 2 different habitats (sand and eelgrass) for $24 \mathrm{~h}$. The 1 -group crabs were tethered in June and the 0-group in September. Data are pooled from 2 different bays

the predation rates for medium (2.6 to $4.0 \mathrm{~mm} \mathrm{CW;} 26$ and $11 \%$ mortality in sand and grass, respectively) and large $(5.0$ to $9.0 \mathrm{~mm} \mathrm{CW} ; 10$ and $4 \%$ mortality in sand and grass, respectively) prey. Proportional molt rate of tethered crabs was significantly higher for the 2 smailer size ciasses ( 20 and $27 \%$ ) than the larger size class $(7 \%)$, but did not differ between habitats or bays (Table 3).

No significant difference was found in relative predation rates between June and September for the 5 to $9 \mathrm{~mm}$ CW size class (ANOVA; $F=0.02, \mathrm{df}=1,56, \mathrm{p}>$ 0.05), suggesting that the habitat refuge found for this size class in the eelgrass in September is weak, since it was not detected in the June experiment.

Table 3. Proportional relative predation rates and proportional molt rate of juvenile shore crabs Carcinus maenas as a function of Habitat (sand and eelgrass), Prey size $(5.0-9.0,10.0-18.0$ and $21.0-25.0 \mathrm{~mm} \mathrm{CW}$ ) and Location (bay 1 and bay 2 ) in June, and as a function of Habitat, Prey size $(1.0-2.5,2.6-4.0$ and $5.0-9.0 \mathrm{~mm} \mathrm{CW}$ ) and Location in September, from the field tethering experiment. Three-factor mixed-model ANOVA tables

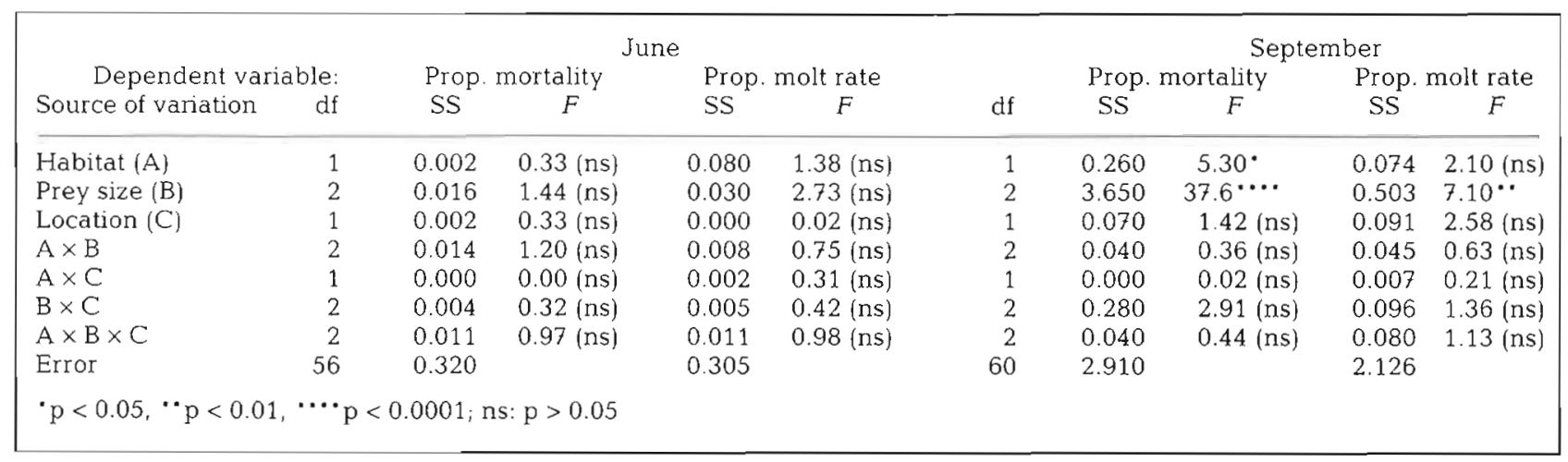




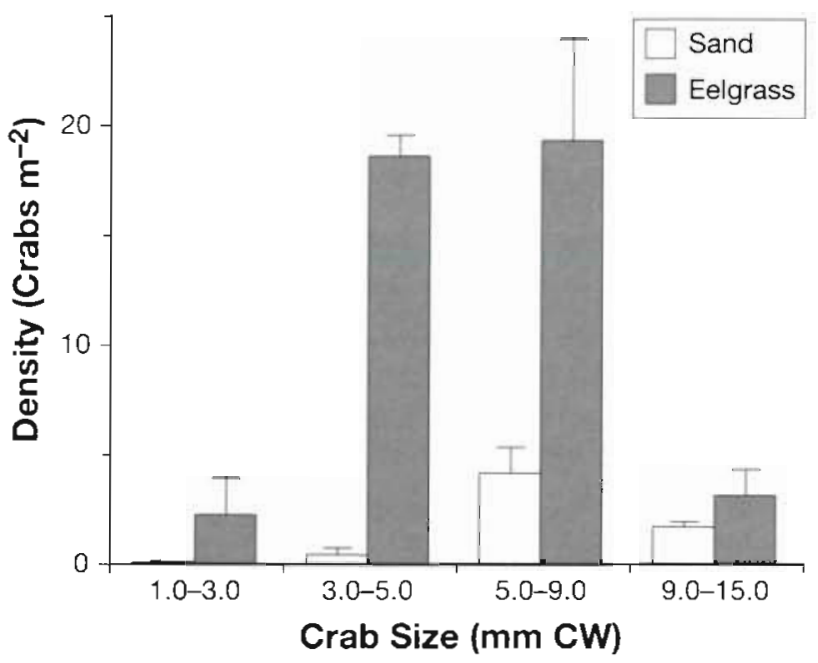

Fig. 5. Carcinus maenas. Densities of 4 size classes of juvenile shore crabs (-SE) in 2 habitats (sand and eelgrass) in September from the 2 bays (pooled) used in the tethering experiment. Crabs smaller than $9 \mathrm{~mm}$ belong to the 0 -group

Drop trap samples showed similar patterns of densities and distribution of juvenile shore crabs $(1$ to $15 \mathrm{~mm}$ CW) in the 2 bays, with higher densities of crabs in the eelgrass habitat ( 38 and 49 crabs $\mathrm{m}^{-2}$ ) than, in the adjacent sand habitat ( 7 and 5 crabs $\mathrm{m}^{-2}$ ), and a higher proportion of crabs larger than $5 \mathrm{~mm} \mathrm{CW}$ in the sand habitat (Fig. 5). Crabs smaller than $5 \mathrm{~mm} \mathrm{CW}$ were found at high densities in the eelgrass habitat $(21 \mathrm{crabs}$ $\mathrm{m}^{-2}$ ), whereas fewer than $2 \%$ were found in the sand habitat $\left(0.5 \mathrm{crabs} \mathrm{m}^{-2}\right)$. The proportion of crabs $5-9 \mathrm{~mm}$ and $9-15 \mathrm{~mm} \mathrm{CW}$ in sand compared to eelgrass was 18 and $35 \%$, respectively.

\section{DISCUSSION}

\section{Settlement mortality and habitat refuges}

Our results suggest that predation causes high mortality for settling shore crab megalopae, and that survival during settlement is dependent on finding shelter. Predation caused significant mortality in all habitats, but blue mussels, eelgrass and filamentous algae provided a significant refuge from predation when compared to open sand habitat. High predation rates on sand ( 80 to $90 \% 48 \mathrm{~h}^{-1}$ ) by natural densities of 2 dominant epibenthic predators suggest that few megalopae that settle and metamorphose in low-refuge habitats will survive. Settling mortality decreased by 60 to $80 \%$ for megalopae provided with structurally complex habitats. Filamentous green algae gave the best refuge from predation, approximately half the mortality (13 to $14 \%$ ) of that in grass and mussels (19 to $33 \%$ ).
Previous field studies have demonstrated sharp decline in juvenile shore crab densities after peak settlement events, suggesting high juvenile mortality (Klein-Breteler 1976, Eriksson \& Edlund 1977, Pihl \& Rosenberg 1982, Beukema 1991, Thiel \& Dernedde 1994). However, these studies did not assess settling mortality, since sampling techniques were not quantitative for megalopae, or distinguish between mortality and migration to explain this decline. The present study is the first to provide support for high predation on settling megalopae and young juvenile shore crabs.

Our results further demonstrate increased settlement survival in structurally complex habitats, which is consistent with other laboratory studies [e.g. postlarval lobsters in cobblestones and salt-marsh peat reefs, Barshaw et al. (1994); mud crab megalopae on shell bottom and macroalgae, Dittel et al. (1996); blue crab megalopae in eelgrass, Olmi \& Lipcius (1991), Moksnes et al. (1997)]. The importance of blue mussel beds as a nursery habitat for juvenile shore crabs has been suggested by several authors (Klein-Breteler 1976, Eriksson \& Edlund 1977, Pihl \& Rosenberg 1982, Thiel \& Dernedde 1994). Our key finding, that refuge was obtained in several different habitats, suggests that shore crab megalopae can use habitats as shelter opportunistically, and are therefore less dependent on a single nursery habitat and less affected by spatiotemporal variation in habitat distribution and availability. Such plasticity may be one reason for the successful establishment of this species in many coastal areas worldwide.

\section{Ephemeral algae as nursery habitats}

Predation refuges in 5 species of ephemeral algae varied dramatically with slight changes in habitat complexity. First instar crabs received a significant refuge in intermediate structural complexity, but not in algae with either lower or higher complexity. Algae with a surface area of 2.2 to $7.3 \mathrm{~m}^{2}$ per $100 \mathrm{ml}$ algae and stem diameter of 0.02 to $5 \mathrm{~mm}$ (Enteromorpha spp. and Cladophora spp.) resulted in a 6 to $24 \%$ mortality under high levels of predation pressure. Qualitative observation made in glass aquaria showed that the first instar crabs could move in-between filaments, where they were well concealed and out of reach of the larger predators. The brown shrimp often got entangled in the filaments, resulting in abdominal (caridoid) reflex (Coen \& Heck 1981) and interrupted search activity. Enteromorpha and Cladophora species make up over $90 \%$ of the biomass of ephemeral algae that intermittently cover up to $50 \%$ of all shallow bays ( 0 to $1 \mathrm{~m}$ ) on the west coast of Sweden during the summer (June to September; Moksnes \& Pihl 1995). The results from the 
present study suggest that Enteromorpha and Cladophora species provide an excellent shelter for settling shore crab megalopae and first instars, and that the increased distribution of these algae may have a positive effect on the recruitment of juveniles. These suggestions are supported by field data showing a longterm increase in the adult population of shore crabs associated with an increase of green algal mats in nursery areas in the Wadden Sea (Reise et al. 1989), and by temporal and spatial correlation between these algal species and juvenile shore crabs on the Swedish west coats (Isaksson \& Pihl 1992). The algae with the highest structural complexity $\left(16 \mathrm{~m}^{2}\right.$ per $100 \mathrm{ml}$ algae), Ectocarpus siliculosus, offered no refuge from predation (86\% mortality) compared to sand. First instar crabs could not move in-between the fine algal filaments (10 to $40 \mu \mathrm{m}$ stem diameter) and became easy prey for the shrimp that could move around the blanket-like surface of the algae without getting entangled. This alga is common in the Gullmarsfjord area in the fall, where it often completely covers an eelgrass bed after a couple of days of calm weather (Moksnes unpubl. data). The algae with the lowest structural complexity $\left(2.0 \mathrm{~m}^{2}\right.$ per $100 \mathrm{ml}$ algae), Ulva lactuca, also provided low protection from predation $170 \%$ mortality). However, field tethering experiments have demonstrated increased survival for juvenile blue crabs (12 to $64 \mathrm{~mm}$ CW) placed within beds of $U$. lactuca (Barshaw \& Abie 1990a, Wilson ei di. 1990). Ii is pussible that this alga can provide refuge for older juvenile shore crabs under more natural conditions. Exudates of $U$. lactuca in combination with low oxygen levels $\left(<25 \% \quad \mathrm{O}_{2}\right.$ saturation) can cause high mortality of first stage blue crab zoea larvae (Johnson \& Welsh 1985). The present study showed no support for such detrimental effects on first instar shore crab from any of the investigated algal species ( 0 to $5 \%$ control mortality), even though we measured oxygen levels below $25 \%$ saturation at night.

Numerous studies have demonstrated a decline in predation efficiency as habitat complexity increases (see review by Coull \& Wells 1983), either after a certain threshold level of complexity is reached (Heck \& Thoman 1981, Savino \& Stein 1982, Gotceitas \& Colgan 1989) or following a linear relationship (Nelson \& Bonsdorff 1990). Total surface area has been suggested as the best estimate of habitat complexity and shelter for invertebrate prey (Dean \& Connell 1978, review by Heck \& Crowder 1991). However, our results indicate that plant morphology and the living spaces provided by the vegetation in relation to the relative sizes of predator and prey (Hacker \& Steneck 1990, Heck \& Crowder 1991) must also be considered when estimating complexity and the refuge value of a habitat. In our study, only the algae which interfered with predator movements and not with prey movements provided a significant refuge from predation, irrespective of surface area.

\section{Habitat and size refuges}

Our field tethering experiment supported laboratory results of high relative predation rates on the newly settled crabs ( 1 to $2.5 \mathrm{~mm} \mathrm{CW}$ ) in the sand habitat ( $67 \%$ mortality $24 \mathrm{~h}^{-1}$ ) and a significant refuge in the eelgrass habitat for the 0 -group crabs. Predation intensity relaxed for crabs larger than $4.0 \mathrm{~mm} \mathrm{CW}$, which experienced similarly low mortality $<10 \%$ mortality $24 \mathrm{~h}^{-1}$ ) in both habitats. Shore crabs spend approximately 4 times longer in the larger instar stages $(5$ to $25 \mathrm{~mm} \mathrm{CW}$ ) then in the vulnerable first to fourth instar stage (Mohamedeen \& Hartnoll 1989), but calculations using the relative daily rates of mortality obtained from this study show that total survival is still approximately 2000 times higher during the larger stages. These results are consistent with the general trend of exponential decrease in mortality during early juvenile life found in marine benthic invertebrates with limited dispersal (Gosselin \& Qian 1997) and suggest that predation can cause a bottleneck (cf. Beck 1997) for juvenile shore crab populations during early juvenile stages. Our results suggest further that larger juveniles attain a strong size refuge from predation by resident predators, indicating that the important predators are small, possibly conspecifics and brown shrimp which are abundant in both habitats. Larger epibenthic predators, such as I-group cod, feed mainly on larger crabs (>4 mm CW; Pihl 1982) and appear to be a less important predator for juvenile shore crabs. Shore birds Larus spp. that are common predators on shore crabs between 10 and $35 \mathrm{~mm} \mathrm{CW}$ on tidal flats in the Wadden Sea (Thiel \& Dernedde 1994 and references therein) are possibly prevented from being efficient predators on the Swedish west coast due to the small tidal amplitude, which rarely exposes the nursery habitats to low water.

Decreased relative predation rates in eelgrass compared to unvegetated habitats have also been demonstrated for tethered juvenile blue crabs in estuarine systems on the U.S. east coast (Wilson et al. 1987, Pile et al. 1996). In contrast to the present results, much higher overall predation rates were shown on larger crabs $\left(70\right.$ to $\left.90 \% 24 \mathrm{~h}^{-1}\right)$, possibly indicating that temperate Western Atlantic eelgrass systems are dominated by larger predators compared to the one in the present study.

Our observational laboratory study supported the idea of small epibenthic predators playing a key role in juvenile shore crab mortality. All of the 7 most abun- 
dant epibenthic predators larger than $15 \mathrm{~mm}$ in shallow bays were efficient predators on the smallest crabs, but only the 1-group shore crabs and the largest size classes of shrimp and fish could eat the 3 to $4 \mathrm{~mm}$ CW prey, and only young adult shore crabs managed to eat prey crabs 6 to $7 \mathrm{~mm}$ in CW. Comparable results have been demonstrated for juvenile spiny lobster Panulirus argus Latreille, where high relative predation rates were found only on smaller juveniles outside nursery habitats (Smith \& Herrnkind 1992). The size refuge was suggested to be caused by a small predator assemblage, which allowed the larger juvenile lobster an ontogenetic shift in habitat use. In the present study, juvenile shore crabs smaller than $5 \mathrm{~mm} \mathrm{CW}$ were concentrated in the nursery habitat (eelgrass), whereas larger juveniles ( 5 to $15 \mathrm{~mm} \mathrm{CW}$ ) were also found in significant $\left(6\right.$ crabs $\left.\mathrm{m}^{-2}\right)$ numbers in the sand habitat. These results may suggest that a trade-off occurs between predator avoidance and requirements of food and/or space by larger juveniles, resulting in a predation-mediated, size-dependent habitat shift and foraging activities outside protective nursery habitats. Similar suggestions have been raised for crayfish (Stein \& Magnuson 1976), American lobster (Wahle \& Steneck 1991) and blue crabs (Pile et al. 1996, Moksnes et al. 1997). However, a large number (23 crabs $\mathrm{m}^{-2}$ ) of juvenile shore crabs $>5 \mathrm{~mm}$ CW still reside in the eelgrass beds during the day, and even higher densities are found in the blue mussel beds (approximately 100 crabs $\mathrm{m}^{-2}$; Moksnes unpubl. data), possibly indicating a behavior adapted for larger epibenthic predators or shore birds prevalent in other areas of the distribution of this metapopulation. Further studies are necessary to identify the important processes for postsettlement movements and distribution of juvenile shore crabs.

\section{Cannibalism}

Cannibalism in shore crabs has received little attention as an important source of mortality for settling megalopae and juveniles. It has been suggested as a potentially important process for juvenile mortality (Reise 1985), but reports have been limited to accidental losses under unnaturally high crab densities in experiments designed to study other processes (KleinBreteler 1975, Scherer \& Reise 1981). Furthermore, limited amounts of conspecifics in stomach analysis of adult crabs has led to the conclusion that cannibalism is unusual in shore crabs because adult and juveniles are living in different habitats (Ropes 1968).

The results from the present study demonstrated that cannibalistic juvenile shore crabs were extremely efficient predators on smaller conspecifics, with predation rates similar to or higher than those of all other investigated predators in all habitats. Juvenile crabs were more efficient predators than adults, which only occasionally consumed a prey crab, even though they readily ate blue mussels immediately before and after the trials. The most efficient cannibals on megalopae and first instar crabs were between 5 and $20 \mathrm{~mm} \mathrm{CW}$ and regularly consumed all 20 megalopae or first instars $\left(24 \mathrm{~h}^{-1}\right.$ predator $\left.^{-1}\right)$. Conspecifics as small as $3 \mathrm{~mm} \mathrm{CW}$ also consumed significant amounts of new recruits. The small size difference necessary for cannibalism enables conspecific predation between cohorts that settle only 2 to $3 \mathrm{wk}$ apart. Cannibalism between crabs of the same size was low (0 to $5 \%$ mortality) and appeared to occur only during ecdysis. Overall, intracohort cannibalism appeared less important for juvenile mortality compared to inter-cohort cannibalism. Rates of cannibalism were not affected by alternative food, and juvenile cannibalistic crabs apparently preferred first instar prey over mussel tissue. Juvenile shore crabs are opportunistic omnivores (Ropes 1968 , Jensen \& Jensen 1985) feeding on the most abundant prey (Scherer \& Reise 1981), and they probably consider smaller conspecifics as any other prey and will feed on them when densities increase above a threshold or above that of other prey species.

In the mesocosm experiment with alternative prey, cannibalism caused 14 to $33 \%$ mortality in nursery habitats in $48 \mathrm{~h}$ in low (16 crabs $\mathrm{m}^{-2}$ ) predator densities. Densities of shore crabs with the potential to consume megalopae and first instars ( 3 to $30 \mathrm{~mm} \mathrm{CW}$ ) often exceed 50 crabs $\mathrm{m}^{-2}$ in Swedish nursery habitats (Isaksson \& Pihl 1992, Moksnes unpubl. data). In the Wadden Sea, maximum settling densities of shore crabs have been reported as high as $2000 \mathrm{~m}^{-2}$ (Scherer \& Reise 1981), suggesting favorable conditions for cannibalistic interactions in nursery habitats during the recruitment season. We suggest that cannibalism among juveniles is a major component of settlement and post-settlement mortality for the shore crab. These suggestions are supported by an increasing amount of data on cannibalism between juveniles of brachyuran crabs (e.g. blue crabs: Perkins-Visser et al. 1996, Moksnes et al. 1997; Dungeness crabs Cancer magister Dana: Fernandez et al. 1993a, b; Japanese grapsid crabs Hemigrapsus penicillatus De Haan: Kurihara \& Okamoto 1987; snow crabs Chionoectes opilio $\mathrm{O}$. Fabricius: Lovrich \& Sainte-Marie 1997). The paradox is that nursery habitats enhance juvenile densities by the combined processes of increased survival and attraction of settling megalopae and migrating juveniles, while also increasing the conditions for cannibalism, thereby decreasing survival (Fernandez et al. 1993a). However, Moksnes et al. (1997) demonstrated that density-dependent agonistic behavior between 
cannibalistic juvenile blue crabs decreased predation rates in high predator densities, leaving the overall predation pressure little affected. Furthermore, recent habitat choice experiments showed that first instar shore crabs preferred filamentous algae as a habitat, whereas juvenile crabs 8 to $10 \mathrm{~mm} \mathrm{CW}$ preferred blue mussels (Hedvall et al. in press), indicating a potential for different juvenile stages to use different nursery habitats, reflecting a possible adaptation to different suites of predators.

Juvenile cannibalism could constitute a self-regulatory mechanism in the recruitment of juvenile shore crabs if the cannibalism is density-dependent. The present study did not investigate the effect of prey and predator densities; further studies are necessary to evaluate these effects.

\section{Implications for recruitment of juvenile shore crabs}

The results in the present study suggest that predation is an important process for the recruitment of juvenile shore crabs, and that settlement and the first month as benthic crabs constitute a predation bottleneck for the juvenile population. The high predation pressure on settling megalopae and first instar crabs in habitats with low structural complexity, and the significant reduction in mortality in nursery habitats, suggest that ine juvenije recruitment is dependent on the availability of shelter-providing habitats. If postlarvae are only passively dispersed, recruitment may be proportional to the availability of nursery habitats, regardless of whether or not these habitats are at carrying capacity (Wahle \& Steneck 1991), and an increase in the distribution of, for example, filamentous algae would have a positive effect on shore crab populations. Habitat specific predation rates alone could then explain the nonrandom distribution of juvenile shore crabs in shallow soft bottom nursery areas. The habitat specific predation rates found in the present study appear to reflect the distribution of juvenile shore crabs in the field, suggesting that predation may be directly responsible. However, recent habitat selection experiments demonstrated that settling shore crab megalopae avoided open sand habitats and actively selected a structurally complex habitat nonspecifically (Hedvall et al. in press). All nursery habitats used in the present study were selected for in equal proportion, except that the alga Ectocarpus siliculosus was less preferred. Predation only partly changed the distribution of settlers by increasing the proportion of megalopae in filamentous algae. These results make it tempting to suggest that the shore crab megalopa has adapted a behavior to decrease predation during settlement, and they indicate that active habitat selec- tion is the major process directly responsible for the nonrandom distribution of juvenile shore crabs. We suggest that habitat-and size-specific predation rates on juvenile shore crabs comprise the major selective force behind active habitat selection of postlarvae and juveniles.

The ability of megalopae to actively select nursery habitats will decrease the correlation between habitat availability and juvenile recruitment, if densities of megalopae and juvenile crabs in these habitats are below carrying capacity. This suggests, together with the ability of settlers to obtain a predation refuge in several different habitats, that the recruitment of juvenile shore crabs should be less affected by variation in the distribution of nursery habitats. However, it is presently not known over what distances active habitat selection in shore crab megalopae and juveniles can concentrate settlers, or to what extent shore crab recruitment is regulated by larval supply or postsettlement density-dependent processes. We encourage further research on these topics to assess the effect of predation and nursery habitats on the population dynamics of the shore crab.

Acknowledgements. We thank Håkan Wennhage and Anna Lundberg for professional help in the tethering experiment, Anders Svensson and Malin Werner for excellent laboratory assistance, Mats Kuylenstierna for identification of filamen-

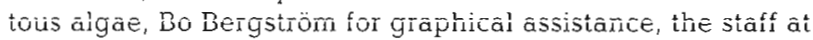
Kristineberg Marine Research Station for providing excellent facilities, and Prof. Rutger Rosenberg, Hans Nilsson, and 4 anonymous referees for helpful comments on the manuscript. This research was made possible through grants from the Swedish Environmental Protection Agency (SEPA), Swedish Council for Forestry and Agricultural Research (SFAR) and World Wide Fund for Nature (WWF) which are kindly acknowledged. This paper constitutes publication number 2116 from the Virginia Institute of Marine Science of The College of William and Mary.

\section{LITERATURE CITED}

Baden SP, Pihl L (1984) Abundance, biomass and production of mobile epibenthic fauna in Zostera marina (L.) meadows, western Sweden. Ophelia 23:65-90

Barshaw DE, Able KW (1990a) Deep burial as a refuge for lady crabs Ovalpes ocellatus: comparison with blue crabs Callinectes sapidus. Mar Ecol Prog Ser 66:75-79

Barshaw DE, Able KW (1990b) Tethering as a technique for assessing predation rates in different habitats: an evaluation using juvenile lobster Homarus americanus. Fish Bull US 88:415-417

Barshaw DE, Able KW, Heck KL (1994) Salt marsh peat reef as protection for postlarval lobsters Homarus americanus from fish and shrimp predators: comparison with other substrates. Mar Ecol Prog Ser 106:203-206

Beck MW (1997) A test of the generality of the effects of shelter bottlenecks in four stone crab populations. Ecology $78: 2487-2503$

Beukema JJ (1991) The abundance of shore crabs Carcinus 
maenas (L.) on a tidal flat in the Wadden Sea after cold and mild winters. J Exp Mar Biol Ecol 153:97-113

Carr MH (1994) Effects of macroalgal dynamics on recruitment of a temperate reef fish. Ecology 75:1320-1333

Coen LD, Heck KL (1981) Experiments on competition and predation among shrimps of seagrass meadows. Ecology 62:1484-1493

Cohen AN, Carlton JT, Fountain MC (1995) Introduction, dispersal and potential impacts of green crab Carcinus maenas in San Francisco Bay, California. Mar Biol 122: $225-237$

Connell JH (1985) The consequences of variation in initial settlement vs. post-settlement mortality in rocky intertidal communities. J Exp Mar Biol Ecol 93:11-45

Coull BC, Wells JBJ (1983) Refuges from fish predation: experiments with phytal meiofauna from the New Zealand rocky intertidal. Ecology 64:1599-1609

Dean RL, Connell JH (1978) Marine invertebrates in an algal succession. III. Mechanisms linking habitat complexity with diversity. J Exp Mar Biol Ecol 109:249-273

Dittel A, Epifanio CE, Natunewicz C (1996) Predation on mud crab megalopae, Panopeus herbstij H. Milne Edwards: effect of habitat complexity, predator species and postlarval densities. J Exp Mar Biol Ecol 198:191-202

Eggleston DB (1995) Recruitment in Nassau grouper Epinephelus striatus: post-settlement abundance, microhabitat features, and ontogenetic habitats shifts. Mar Ecol Prog Ser 124:9-22

Eggleston DB, Armstrong D (1995) Pre- and post-settlement determinants of estuarine Dungeness crab recruitment. Ecol Monogr 65:193-216

Eriksson S, Edlund AM (1977) On the ecological energetics of 0-group Carcinus maenas (L.) from shallow sandy bottom in Gullmar fjord, Sweden. J Exp Mar Biol Ecol 30:233-248

Fernandez M, Armstrong D, Iribarne O (1993b) First cohort of young-of-the-year Dungeness crab, Cancer magister, reduces abundances of subsequent cohorts in intertidal shell habitat. Can J Fish Aquat Sci 50:2100-2105

Fernandez M, Iribarne O, Armstrong D (1993a) Habitat selection by young-of-the-year Dungeness crab, Cancer magister, and predation risk in intertidal habitats. Mar Ecol Prog Ser 92:171-177

Gaines SD, Roughgarden J (1987) Fish in offshore kelp forest affect recruitment of intertidal barnacle populations Science 235:479-481

Gosselin LA, Qian PE (1996) Early post-settlement mortality of an intertidal barnacle: a critical period for survival. Mar Ecol Prog Ser 135:69-75

Gosselin LA, Qian PE (1997) Juvenile mortality in benthic marine invertebrates. Mar Ecol Prog Ser 146:265-282

Gotceitas V. Colgan P (1989) Predator foraging success and habitat complexity: quantitative test of the threshold hypothesis. Oecologia (Berlin) 80:158-166

Hacker SD, Steneck RS (1990) Habitat architecture and the abundance and body-size-dependent habitat selection of a phytal amphipod. Ecology 7:2269-2285

Heck KL, Crowder LB (1991) Habitat structure and predatorprey interaction in vegetated aquatic systems. In: Bell S, McCoy E, Mushinsky H (eds) Habitat structure: the physical arrangement of objects in space. Chapman and Hall, New York, p 281-299

Heck KL, Orth RJ (1980) Structural components of eelgrass (Zostera marina) meadows in the lower Chesapeake Bay-decapod Crustacea. Estuaries 3:289-295

Heck KL, Thoman TA (1981) Experiments on predator-prey interactions in vegetated aquatic habitats. J Exp Mar Biol Ecol 53:125-134
Hedvall O, Moksnes PO. Pihl L (in press) Habitat selection in postlarvae and juveniles of the shore crab, Carcinus maenas. A laboratory study in an annular flume. Hydrobiologia

Hermkind WF, Butler MJ IV (1986) Factors regulating postlarval settlement and juvenile microhabitat use by spiny lobsters, Panulirus argus. Mar Ecol Prog Ser 34:23-30

Isaksson I, Pihl L. (1992) Structural changes in benthic macrovegetation and associated epibenthic faunal communities. Neth J Sea Res 30:131-140

Jensen KT, Jensen JN (1985) The importance of epibenthic predators on the density of juvenile benthic macrofauna in the Danish Wadden Sea. J Exp Mar Biol Ecol 89:157-174

Johnson DA, Welsh BL (1985) Detrimental effects of Ulva lactuca (L.) exudates and low oxygen on estuarine crab larvae. J Exp Mar Biol Ecol 86:73-83

Keough MJ, Downes BJ (1982) Recruitment of marine invertebrates: the role of active larval choices and early mortality. Oecologia 54:348-352

Klein-Breteler WCM (1975) Laboratory experiments on the influence of environmental factors on frequency of molting and increase in size at molting of juvenile shore crabs, Carcinus maenas. Neth J Sea Res 9:100-120

Klein-Breteler WCM (1976) Settlement, growth and production of the shore crab. Carcinus maenas, on tidal flats in the Dutch Wadden Sea. Neth J Sea Res 10:354-376

Kurihara Y, Okamoto K (1987) Cannibalism in a grapsid crab, Hemigrapsus penicillatus. Mar Ecol Prog Ser 41:123-127

Lovrich GA, Sainte-Marie B (1997) Cannibalism in the snow crab, Chionoecetes opilio (O. Fabricius) (Brachyura: Majidae), and its potential importance to recruitment. J Exp Mar Biol Ecol 211:225-245

Menge BA, Sutherland JP (1987) Community regulation: variation in disturbance, competition, and predation in relation to environmental stress and recruitment. Am Nat 110: $351-369$

Mohamedeen H, Hartnoll RG (1989) Larval and postlarval growth of individually reared specimens of the common shore crab Carcinus maenas (L.). J Exp Mar Biol Ecol 134: 25-36

Moksnes PO, Lipcius RN, Pihl L, van Montfrans J (1997) Cannibal-prey dynamics in juveniles and postlarvae of the blue crab. J Exp Mar Biol Ecol 215:157-187

Moksnes PO, Pihl L (1995) Utbredning och produktion av fintrådiga alger i grunda mjukbottensområden i Göteborgs och Bohos län. Länsstyrelsen i Göteborg och Bohus län, Miljöavdelningen 10:1-22

Nelson WG, Bonsdorff E (1990) Fish predation and habitat complexity: are threshold levels real? J Exp Mar Biol Ecol 141:183-194

Olmi EJ, Lipcius RN (1991) Predation on postlarvae of the blue crab, Callinectes sapidus Rathbun, by sand shrimp, Crangon septemspinosa Say and grass shrimp, Palaemonetes pugio Holthuis. J Exp Mar Biol Ecol 151:169-183

Perkins-Visser E, Wolcott TG, Wolcott DL (1996) Nursery role of seagrass beds: enhanced growth of juvenile blue crabs (Callinectes sapidus Rathbun). J Exp Mar Biol Ecol 198: 155-173

Peterson CH, Black R (1994) An experimentalist's challenge: when artifacts of intervention interact with treatments. Mar Ecol Prog Ser 111:289-297

Pihl $L$ (1982) Food intake of young cod and flounder in a shallow bay on the Swedish west coast. Neth J Sea Res 15:419-432

Pihl L (1985a) Food selection and consumption of mobile epibenthic fauna in shallow marine areas. Mar Ecol Prog Ser 22:169-179 
Pihl L (1985b) Mobile epibenthic population dynamics, production, food selection and consumption on shallow marine soft bottoms, western Sweden. PhD thesis, Göteborg University

Pihl L, Isaksson I, Wennhage H, Moksnes PO (1995) Recent increase of filamentous algae in shallow Swedish bays: effects on the community structure of epibenthic fauna and fish. Neth J Aquat Ecol 29:349-358

Pihl L, Magnusson G, Isaksson I, Wallentinus I (1996) Distribution and growth of ephemeral macroalgae in shallow bays on the Swedish west coast. J Sea Res 35:169-180

Pihl L, Rosenberg R (1982) Production, abundance, and biomass of mobile epibenthic marine fauna in shallow waters, western Sweden. J Exp Mar Biol Ecol 57:273-301

Pihl L, Rosenberg R (1984) Food selection and consumption of the shrimp Crangon crangon in some shallow marine areas in western Sweden. Mar Ecol Prog Ser 15:159-168

Pile AJ, Lipcius RN, van Montfrans J, Orth RJ (1996) Density dependent settler:recruit:juvenile relationships in blue crabs: mechanisms and effects of a tropical storm. Ecol Monogr 66:277-300

Polis GA (1981) The evolution and dynamics of intraspecific predation. Annu Rev Ecol Syst 12:225-251

Reise K (1985) Tidal flat ecology. Springer-Verlag, Berlin

Reise K, Herre E, Sturm M (1989) Historical changes in the benthos of the Wadden Sea around the island of Sylt in the North Sea. Helgoländer Meeresunters 43:417-433

Ropes JW (1968) The feeding habits of the green crab, Carcinus maenas (L.). Fish Bull US 67:183-203

Sanchez-Salazar ME, Griffiths CL, Seed R (1987) The effect. of size and temperature on predation of cockles Cerastoderma edule (L.) by the shore crab Carcinus maenas (L.). J Exp Mar Biol Ecol 111:181-193

Savino JF, Stein RA (1982) Predator-prey interaction between largemouih bass dnù bluegihls as infiuenced by sinnuiated

Editorial responsibility: Otto Kinne (Editor), Oldendorf/Luhe, Germany vegetation. Trans Am Fish Soc 111:255-266

Scheltema RS (1974) Biological interactions determining larval settlement of marine invertebrates. Thalassia Jugosl 10:263-296

Scherer B, Reise K (1981) Significant predation on micro- and macrobenthos by the crab Carcinus maenas L. in the Wadden Sea. Kieler Meeresforsch Sonderh 5:490-500

Smith KN, Herrnkind WF (1992) Predation on early juvenile spiny lobsters Panulirus argus (Latreille): influence of size and shelter. J Exp Mar Biol Ecol 157:3-18

Sokal RR, Rohlf FJ (1981) Biometry. WH Freeman, New York Stein RA, Magnuson JJ (1976) Behavioral response of crayfish to a fish predator. Ecology 57:751-761

Thiel M, Dernedde T (1994) Recruitment of shore crabs Carcinus maenas on tidal flats: mussel clumps as an important refuge for juveniles. Helgoländer Meeresunters 48:321-332

Underwood AJ (1997) Experiments in ecology: their logical design and interpretation using analysis of variance. Cambridge University Press, Cambridge

van Montfrans J, Peery CA, Orth RJ (1990) Daily, monthly and annual settlement patterns by Callinectes sapidus and Neopanope sayi megalopae on artificial collectors deployed in York River, Virginia 1985-1988. Bull Mar Sci 46:214-229

Wahle RA, Steneck RS (1991) Recruitment habitats and nursery grounds of the American lobster Homarus americanus: a demographic bottleneck? Mar Ecol Prog Ser 69: 231-243

Wilson K, Able KW, Heck KL Jr (1990) Predation rates on juvenile blue crabs in estuarine nursery habitats: evidence for the importance of macroalgae (Ulva lactuca). Mar Ecol Prog Ser 58:243-251

Wilson K, Heck KL, Able KW (1987) Juvenile blue crab, Callinectes sapidus, survival: an evaluation of eelgrass, Zostera marina, as a refugc. Fish Bull US 85:53-58

Submitted: November 27, 1997; Accepted: March 13, 1998

Proofs received from author(s): April 27, 1998 